\title{
Current Insights on Translation Studies
}

\author{
Rochmat Susanto \\ Applied Linguistics, Post Graduate Program \\ Yogyakarta State University \\ Sleman, Indonesia \\ susantogolpdp15@gmail.com
}

\author{
Sufriyati Tanjung \\ Applied Linguistics, Post Graduate Program \\ Yogyakarta State University \\ Sleman, Indonesia \\ sufriati@uny.ac.id
}

\begin{abstract}
This paper proposes current insights on translation studies which essentially cover two subject matters. Firstly, it provides classifications toward the abundant definitions of translation as stated by translation scholars. Secondly, it gives broader view that translation act is not merely concerned with lingual or commonly bilingual expressions as assumed by many people in general or even translation scholars who still have outdated view. In providing classification toward the abundant definitions of translation, it was found that basically all of the definitions stated by translation scholars can be classified into three categories: as a process, a product and a phenomenon. Having explored further, it turns out that most translation scholars define translation as a process. The outdated or traditional paradigm in viewing translations is disputed by the concept of translatics. This concept gives a broader insight that translation is not merely involving two different languages in terms of bilingual translation in form of lingual expressions but also involving non-lingual expressions in terms of semiotic-based communication.
\end{abstract}

Keywords-translation studies; translation definitions; translatics

\section{INTRODUCTION}

Translation science known as translation studies turned out to have a very long history to becoming a mature discipline as familiarized today. Before becoming a science, the practice itself is called translation act. If revisit or flash back far backward, it turns obtained something very surprising and astonishing related the origin of translation. Relying on hermeneutic-based translation experts, Schulte and Biguenet [1] proposed a shocking statement while opening wider horizons. As quoted in Tou [2], Schulte and Biguenet [1] states clearly that all forms of communication act is a translation act. Departing from these shocking statements, it can be deduced that the acts of translation have existed since the act of communication existed. Relying on this statement, if it is studied further the act of translation certainly existed long ago before humans were created.

Essentially, the visible and empirical communication is done by humans after being created. As it is known that the existence of humans themselves some say 200,000 years ago and some say more than 2,000,000 years ago. Nevertheless the written language which has always been the sole object of translation studes until now existed about 6000 years ago precisely found in Mesopotamia. It is then believed that the translation and bilingual writing act was firstly begun in about 4500 years ago (see [3]). The period is believed by many experts as the era of the emergence of bilingual translation acts.

Although the act of translation has been done since the ancient times, the science which empirically and clinically studies translation only firstly began to appear in the early first century AD. The pioneer of translation as a study or science is Cicero (the first pioneer in the first century AD). The author found the remark in a book written by Munday and in an article written by Tou [2, p. 19]. In those sources it is said that Cicero began to study translation by issuing the terms "word for word" and "sense for sense". The term is still used today by modern translation experts to classify translations. Then long after the era of Cicero and Jerome, at the beginning of the 19th century precisely in the 1960s then the study of translation was officially declared as a science. Beginning in 1958 two French linguists Jean Paul Vinay and Jean Darbelnet proposed a comparative study of French and English. Then in 1964 Eugene Nida published a book entitled Toward $a$ Science of Translating which clearly mentions the science of translation. Then a year later came John C. Catford in 1965 incorporating a linguistic perspective in translation studies. Seven years later, there appeared James S. Holmes a pioneer of the term "translation studies" with his famous paper presented at an applied linguistic congress held in Copenhagen in 1972. In his paper entitled The Name and Nature of Translation Studies Holmes made a comprehensive taxonomic review map of translation. Then the map was popularized by Toury as written in his book entitled Descriptive Translation Studies and Beyond published in 1995. After 1995, many new streams emerged in translation studies such as skopos, cultural-based translation, and eco-translations.

As has been known from the description above that translation scholars and translation theories have developed so rapidly. However, until now there is confusion related to the notion of "translation" given by translation scholars. Those notions have not given clear boundaries that they have not been sustained by a qualified academic foundation, so it is no doubt that it confuses the academicians and the translation theory learners. Then after randomly interviewing 10 students majoring in English literature, the authors found surprising findings related to traditional persistent views of translations which only seem to involve text from source text translated into target text and engaging only bilingual languages. As a result it needs attention.

Based on the description of the problems described above, this paper focuses on two main issues: to provide clear-cut 
boundaries toward classification of all translation definitions proposed by translation experts and to provide a broader horizon in viewing translation through involving semiotics study because generally the general public and even academics still have a traditional paradigm in viewing the translation as mentioned above.

\section{DISCUSSION}

This section presents the issues that are the focus of this paper one by one including providing clear-cut boundaries in defining the notions of translation, and providing new insight in viewing translation in terms of semiotics. Further explanation is described as follows.

\section{A. Clear-cut Boundaries of Translation Notions}

First, Since the first time translation has been declared as a field of science since the Nida's era (1964) which mentions the first time with the term "a science of translation", until now there are some scientists from various schools of thought who have their own ideals by calling the science of translation in their respective terms. This is because there is no consensus that agrees on the one single mention on the term of translation science. Although in proposing a term, experts are not haphazard in giving it. In this case the experts have a basic deliberation and calculation. However, although the terms coined are different, essentially they have a foundation of the same concept. Cited in Holmes, Newmark and Tou based on a map of the taxonomic study of translation, there is a wide variety of terms to describe the theory or science of translation such as; (1) translation (as theory), (2) principles of translation, (3) fundamentals of translation, (4) philosophy of translation, (5) translatology, (6) translatics, (7) translation theory, (8) translation science, the most popular is (9) translation studies.

Related to the difference term in calling the science of translation, in fact it is not too disturbing because it is still within the boundary of the same concept. The interesting thing precisely occurs in giving the definition of translation itself. Experts give definitions as though without seeing what boundary or basis they use to define. Therefore the definitions that are coined frequently interfere the understanding of translation theory learners.

If it is traced thoroughly, there are already experts who critically giving clear-cut boundaries toward the notions of translation, for example Holmes (1988: 69-71), Newmark (1988) and Tou (1997: 142) who have clear-cut boundary in classifying translation definitions namely as phenomenon, processes, and products. Nevertheless those three experts have not been comprehensively up to give the exemplary definition of translation from various experts based on each boundary. Therefore in this paper, the author gives examples of definitions given by experts and at the same time grouping them into each of those boundaries. This needs to be done in order to build an understanding of the translation definitions as a phenomenon, process, or product resulting from the effort. To achieve this the authors sort out the definitions of some experts to be exemplified into each boundary.
Viewing translation definition as a phenomena, Catford (1978: 20) states "the replacement of textual material in one language (SL) by equivalent textual material in another language (TL).”. This definition essentially sees translation as a phenomenon of replacement of textual material from the source language to the target language. Then Robinson (2005: 6 ) defines translation "... as a representation or reproduction of the original text." The definition also essentially regards translation as a phenomenon which also means restatement of the source language text to the target language text.

Besides regarded as a phenomenon, translation is also considered by some experts as a "process". Nida and Taber (2003: 12) states that "translation is not only the process of reconstructing by searching for the equivalent of the sourcelanguage message, first in terms of meaning and secondly in terms of style." Therefore translation does not merely reconstruct the process by finding the most appropriate meaning equivalence into the target language, but also adjust the style of language appropriate or reasonable which applied in the target language. Further Catford (1965:1) defines "translation is an operation performed on language: a process of substituting a text in one language for a text in another." It means that Catford also defines translation as a process. Then also viewing translation as a process, Larson (1984: 3) states "translation consists of transferring the meaning of the source language into the receptor language. This is done by going from the form of the first language to the form of a second language by way of semantic structure. It is meaning which is being transferred and must be held constant." Besides the experts mentioned above there are many experts who define translation as a process. They are Brislin (1976), Newmark (1988), Duff (1959) dalam Sumarni, (2016: 3), Bell (1991), Simatupang (2000) Bassnett (2002), Widymartaya (2003) dan Munday (2008).

In addition to the definition of translation as a phenomenon and process, there are also some experts who provide translation as a product. Hatim and Munday (2004: 3) define translation as "the second sense center on the concrete translation product produced by the translator". Then Shuttleworth and Cowie (1997: 181), Bussmann (1998: 1222), also state that translation is a product resulting from a translation process. In addition to the various experts who partially provide the definition of translation as described above, there are also experts who comprehensively provide the definition of translation as phenomena, processes, and products at once. They are Shuttleworth and Cowie (1997:181) and Basil Hatim and Jeremy Munday, (2004:6).

From the elaboration of the various definitions of translation coined by the experts above, it can be deduced that although there are three classifications of translation definitions as processes, phenomena, and products in general translation experts tend to coin the definition of translation as a process. This is marked by the most definitions that have been found by authors from various sources. While the definition of translation as a phenomenon possesses the second rank and then followed by the definition of translation as a product. 


\section{B. Translation Viewed in Terms of Semiotics Point of View}

The study of translation in the 21st century has undergone a very significant development. Various scholars from various schools are emerging. Some bring a new view and some are just criticizing the existing theory. Those who bring new views are often not well-marked so that the views of many academic societies tend to be outdated or traditional. This is ultimately proven after the author conducted a small interview with 10 students of English literature. The interview only uses one question instrument: "What is the definition of translation?" The surprising finding proved that 9 out of 10 students answered "changing the text in one language into another." One other student replied did not know. From these findings it can be hinted that the paradigm of translation is still very traditional. To this end, the author intends to give insight into the current view of translation.

Previously it is true that traditionally translation is an act of transferring the meaning of the source text that speaks " $\mathrm{A}$ " into the target text that speaks "B". That kind of statement has been embraced by translation experts for a long time. Therefore it is not surprising that the results of the interview say so.

Departing from the statement of the expert hermeneutical school, it inspires Tou [2] to provide a new insight in translation. This is reinforced by the statements of scholars who believe that translation is an interdisciplinary scholarly branch of "a house of many rooms" that listens to the various points of view of other scholars of many disciplines (Neubert and Shreve 1994: vii-xiv, Hatim 2001: 8-11). Then Tou [2] incorporated asemiotics initiated by Sebeok (2001) in translation so that the combination produces the term "translatics" which is a new term in translation studies seen from the perspective of semiotic study.

Translatics has a broader horizon in viewing translation because it adopts a semiotic study that examines communication globally which means not only involving lingual signs but also non-lingual signs. Therefore according to that understanding, the study of translation becomes increasingly complex and comprehensive. Translatics believes that there is no such thing as original or translated text. The original text is the result of a translation from the author's mind into the sign of writing. Not only that, people talk is also stated as an act of translation.

Tou in his paper clearly illustrates that the classification of translation in translatics seen from semiotics involved is classified into three, which is described in the following figure [2].
TABLE I. KINDS OF TRANSLATION IN TERMS OF TRANSLATICS (AS INSPIRED BY [2])

\begin{tabular}{|c|c|cc|}
\hline \multicolumn{4}{|c|}{ Translatics } \\
\hline $\begin{array}{c}\text { Lingual to Lingual } \\
\text { Translation Act }\end{array}$ & $\begin{array}{c}\text { Lingual to Non- } \\
\text { lingual Translation Act }\end{array}$ & $\begin{array}{c}\text { Non-lingual to } \\
\text { Non-lingual } \\
\text { Translation Act }\end{array}$ & \\
\hline
\end{tabular}

Since translatics covers all kinds of communication both verbal and non-verbal, it is obvious that it covers broader coverage in translation acts. Translation activities from language to language must have been very familiar among academic community such as translation done from English source text into Indonesian target text. While the translations act from language to non-language or vice versa for example activities or phenomenon of translation of the novel into the performance stage has not been much studied. Furthermore, translation activities from non-languages to non-languages as an example of translation of temple reliefs into dances have never also been studied.

\section{CONCLUSION}

There are two main points in this paper. The first is giving clear-cut boundaries toward classification of the definitions of translation and the second is giving a current insight in viewing translation in terms of semiotic-based point of view.

The discussion on the first point draws a conclusion that the translation experts provide the definition of translation into three kinds of boundaries: translation as phenomenon, process, and product. However it turns out that the most definitions that have been found by authors from various sources are translation as a process. While the definition of translation as a phenomenon possesses the second rank and then followed by the definition of translation as a product.

Then the last discussion related to the view of translatics in the explanation above clearly provides a breakthrough in the realm of translation. It has opened new gateways for translation experts to conduct several studies related to acts involving the translation of non-language aspects. Considering that previously translation focuses on lingual expressions only.

\section{REFERENCES}

[1] Schulte, R. and Biguenet, J. (1992). Introduction. Schulte, R. and Biguenet, J. [eds.]. Theories of Translation: An Anthology of Essays from Dryden to Derrida. Chicago and London: The University of Chicago Press Ltd. 1-10.J. Clerk Maxwell, A Treatise on Electricity and Magnetism, 3rd ed., vol. 2. Oxford: Clarendon, 1892, pp.68-73.

[2] Tou, A.B. (2008). The Translatics of Translation. Article, Journal of Modern Languages, Vol. 18, ISSN 1675-526X, 2008, Faculty of Languages and Linguistics, Universiti Malaya, Jabatan Penerbitan Universiti Malaya, Pantai Valley, 50603 Kuala Lumpur, 2008:15-40.

[3] Tou. A.B. November 2005. Applying CBC to EFL Education in Indonesia: Competency-based and Genre-based Models in Contact. Linguistik Terapan. A Journal of Applied Linguistics. 2:2. ISSN 02165139. Medan: Postgraduate School. Medan State University. 97-118. 